\title{
Factors Influencing Attitudes and Intention to Purchase Counterfeit Luxury Brands among Indonesian Consumers
}

\author{
Anas Hidayat ${ }^{1} \&$ Ayu Hema Ajeng Diwasasri ${ }^{1}$ \\ ${ }^{1}$ School of Business and Economics, Universitas Islam Indonesia, Yogyakarta, Indonesia \\ Correspondence: Anas Hidayat, International Program, School of Business and Economics, Universitas Islam \\ Indonesia, Yogyakarta, Indonesia. Tel: 62-274-898-444 ext.2200. E-mail: anas.hidayat@uii.ac.id
}

Received: March 17, 2013

Accepted: April $272013 \quad$ Online Published: July 16, 2013

doi:10.5539/ijms.v5n4p143

URL: http://dx.doi.org/10.5539/ijms.v5n4p143

\begin{abstract}
The aim of the present research study is to examine the influence of antecedents of attitudes towards counterfeiting products of Indonesian consumers and its relationship to purchase intention of counterfeit products. The research mainly discussed the effect of social factors and personality factors towards consumer attitudes to buy counterfeit product, in this context is handbags. Approximately 250 respondents aged from 16-40 participated to give response for the survey gathered from questionnaire distribution. The analysis using path coefficient analysis show that social and personality factors has mostly significant impact towards attitudes. The study concluded that the more positive attitude of consumers towards counterfeit products will further strengthen the purchasing intentions while the higher the status of a consumers' consumption will not affect any change to both their attitude and willingness to purchase counterfeit products.
\end{abstract}

Keywords: social factors, personality factors, attitudes towards counterfeiting products, purchase intention, status consumption

\section{Introduction}

Counterfeiting, the production and sale of fake products that seem identical to the original product, has been mushrooming across the globe and recently growth in dangerous level (Penz \& Stottinger, 2005). Furthermore, Indonesia is among several offenders mentioned in a US report targeting the world's worst piracy offenders who will soon see their illegal market overtaken by the Internet, which is increasingly the sales medium instead of shopping mall stalls and street carts (Jakarta Globe, accessed on October 15, 2012). According to U.S. Customs and Border Protection Office of International Trade (2007), 70 percent of counterfeited goods belong to fashion goods, such as handbags, watches, jewelry, shoes, clothes, hats, sunglasses, and perfume.

The current collective buying behavior shows a high demand for luxury brands product by shoppers at many different social classes. Consumers have increased their awareness about design and have begun to expect high style (Kay, 1990). Consumers who are buying luxury brands products may be described as self-conscious and they were especially concerned about the impression they make (Penz \& Stottinger, 2005). Fashion counterfeit products are believed to carry a high image and the prestige connected to a well-known brand name. The similarities in appearance, quality, and image created by the counterfeited version compared to the original product are important in determining consumers' purchase intention (Wee et al., 1995).

This paper attempted to explore the Indonesian consumers' mindset in relation to purchasing counterfeits of luxury brands. The result and model of the previous research had a conclusion which might not be proper to be applied with the recent condition in Indonesia. The research conducted by the previous researcher has differed in location, object, subject, time and or analysis and generally it was conducted in the foreign country which has different economic and cultural environment to Indonesia. There are three main objectives of the current study. First, it examines the influence of social and personality factors to attitudes towards counterfeit products of Indonesian consumers. Second, it investigates the relationship between consumer attitudes and purchase intention of counterfeits of luxury brands. Third, it examines the influence of social and personality factors to purchase intention of counterfeit products. The producers and marketers of genuine products could then come up with ways or different strategies in engaging the consumers to buy the genuine products over the counterfeit products. 


\section{Literature Review and Hypotheses Development}

\subsection{Attitudes towards Counterfeiting}

According to Huang et al. (2004), attitude is a learned predisposition to respond to a situation in a favourable or unfavourable way. The factors of attitude is often used as a predictor of consumer intentions and behaviours. As attitudes cannot be observed directly, researchers must rely on determining consumer attitudes through measurements (Huang et al., 2004). In view of the consumers, attitudes towards counterfeiting products can be influenced by a number of antecedents. Based on the previous research evidences, the antecedents of attitude can be divided into two groups, namely social factors and personality factors.

Social factors including the likes of normative and informational susceptibility towards social influence. Social influence reflects on what others judment of an individual consumer's behaviour (Ang et al., 2001). Two different forms of consumer susceptibility are information susceptibility and normative susceptibility (Wang et al., 2005). Information susceptibility refers to purchase decision made by consumers based on the expert opinion of others (Ang et al., 2001; Wang et al., 2005), while the normative susceptible person might made a decision based on expectations of what would impress others.

H1a : Social Factors have a negative influence on consumer attitudes towards counterfeit products.

Personality factors such as value consciousness, integrity, personal gratification, novelty seeking, and status consumption. Lichtenstein, et al. (1990) defines value consciousness as a concern to pay in a low price, while expecting to a certain quality constraint. Phau and Teah (2009) offer that there is a significant relationship between consumers' level of value consciousness and their likelihood of buying counterfeit luxury brands, suggesting that value-conscious consumers may see counterfeit products as a better deal than the actual status brand.

H1b : Value consciousness has a positive influence on consumer attitudes towards counterfeit products.

Novelty seeking consumers are particularly interested in products with low purchase risk. Therefore, the low cost of counterfeit products is well suited to satisfying their curiosity and the need for experimentation (Wee et al., 1995). However, Phau and Teah (2009) asserts that novelty seeking has no significant relationship towards attitudes of counterfeit products.

H1c : Novelty seeking has a positive influence on consumer attitudes towards counterfeit products.

Integrity is found to have strong significant influence to social consequences of consumer attitudes towards counterfeit products (Phau and Teah, 2009). Moreover, if the consumers view integrity as critical, the chances of them viewing counterfeit products as an alternative would be less, but if the consumers do not feel that integrity is important then they would be less guilty viewing counterfeit products (Ang et al., 2001; Wang et al., 2005).

H1d : Integrity has a negative influence on consumer attitudes towards counterfeit products.

Personal gratification is the need for a sense of accomplishment, social recognition, and the desire to enjoy the finer things in life (Ang et al., 2001; Wang et al., 2005). Furthermore, Ang et al. (2001) reveal that there is no significant influence of personal gratification on consumer attitudes toward counterfeits. While in the contrary, some studies found that personal gratification proven to have significant negative relationship towards attitudes of counterfeits (Phau and Teah, 2009; Nordin, 2009)

H1e : Personal gratification has a negative influence on consumer attitudes towards counterfeit products.

Husic and Cicic (2009) assert that by using status goods as symbols, individuals are able to communicate impressively about themselves to their reference groups. Previous research found that status consumption seems to consistently influence attitudes of counterfeits (Phau and Teah, 2009), admittedly, there is also different result shown from another literature that status consumption has no effects on attitudes towards counterfeit products (Nordin, 2009).

H1f : Status consumption has a negative influence on consumer attitudes towards counterfeit products.

\subsection{Purchase Intention - Theory Of Planned Behavior (TPB)}

According to the theory of planned behavior (TPB), purchase intention is a good determinants of purchase behavior, in which the purchase intention is in turn determined by attitudes (Phau and Teah, 2009). Attitudes towards behavior instead of towards the product are important to be a better predictor of behavior (Phau and Teah, 2009; Penz and Stottinger, 2005). Several studies found that attitudes towards counterfeit products plays an important positive influence to purchase intention (Phau and Teah, 2009; Nordin, 2009; De Matos et al., 2007; 
Huang et al. 2004). The more favorable consumer attitudes towards counterfeiting are, the higher the chances that consumers will purchase counterfeit brands (Wee et al., 1995).

H2 : There is a significant relationship between attitude and purchase intention towards counterfeits products.

Social and personality antecedents have long been established to have an influence on consumers' decision-making towards purchase intention (Nordin, N., 2009). Previous research shown significant influence of factors of attitudets on purchase intentions. Moreover, the tendency of the positive respondents' attitude towards the counterfeit bags, gives the stronger encouragement towards the intention to buy the counterfeit bags (Budiman, 2012).

H3a : Social Factors has a significant relationship to the purchase intention of counterfeit products.

H3b : There is a significant relationship between value consciousness and purchase intention of counterfeit products.

H3c : There is a significant relationship between novelty seeking and purchase intention of counterfeit products.

H3d : There is a significant relationship between integrity and purchase intention of counterfeit products.

H3e : There is a significant relationship between personal gratification and purchase intention of counterfeit products.

H3f : There is a significant relationship between status consumption and purchase intention of counterfeit products.

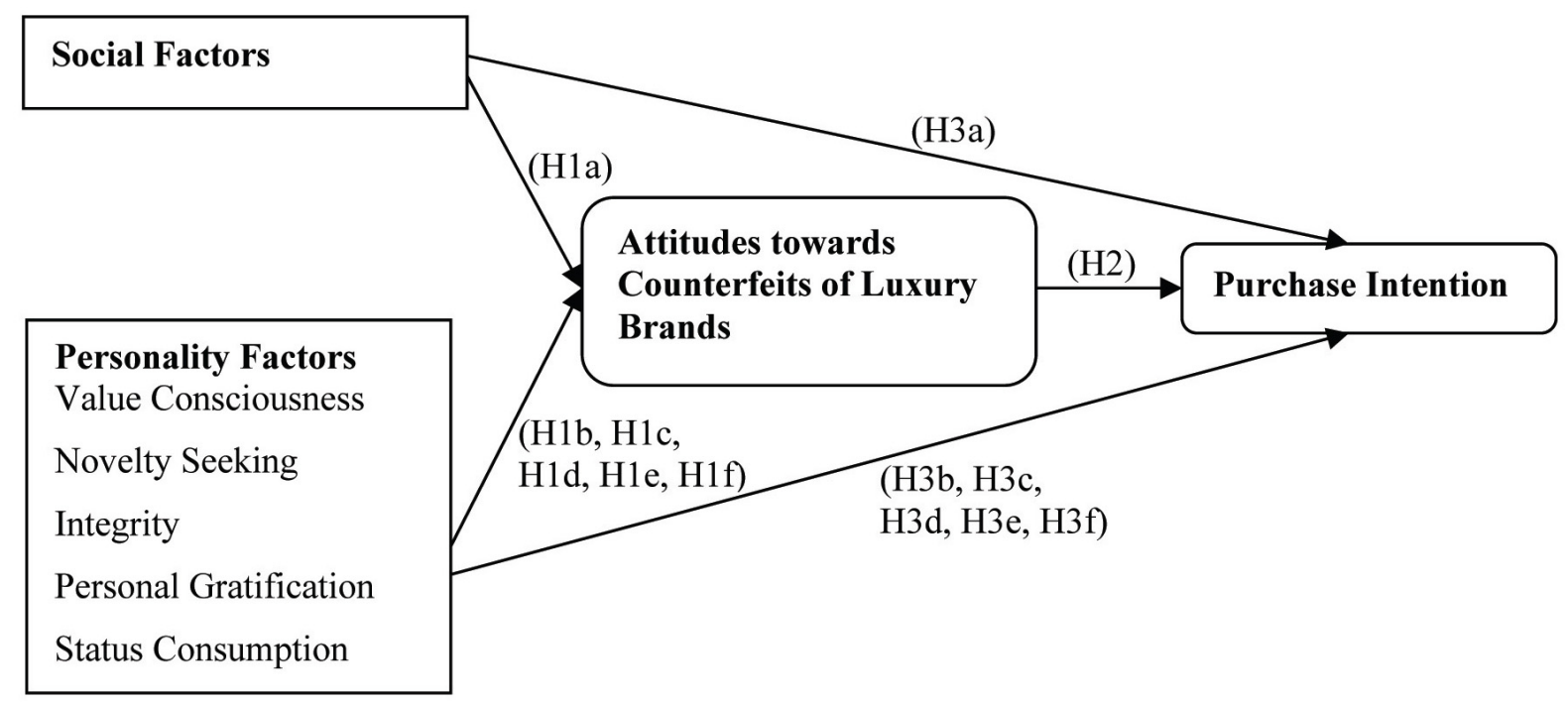

Figure 1. The conceptual framework of the study

\section{Research Method}

\subsection{Type and Source of Data}

The primary data of this research is gathered from questionnaire distribution. The questionnaire is developed based on seven-point likert-scale adopted from Phau and Teah (2009 and Noordin (2009). This research used quantitative approach with quota-purposive convenience sampling method and all methods of data collection were conducted from September 2012 until November 2012 in the area of Sleman, Yogyakarta, mostly around Universitas Islam Indonesia Yogyakarta, Indonesia. The number of the sample obtained was 265 respondents; however, the number of samples was reduced when the respondent failed to answer the questionnaire completely. A total of 250 samples were considered acceptable after being tested the reliability and validity, and then entered into SPSS 16.0 to be calculated using path analysis with an approach to regression analysis for hypothesis testing. Coefficient of the parameter is estimated using Standardized Coefficient while the methods used to calculate the path coefficient is Ordinary Least Square (OLS). 


\subsection{Survey Instrument}

The questionnaire was adopted from Phau and Teah (2009), Bearden et al. (1989), Lichtenstein et al. (1990), de Matos et al. (2007), Wee et al. (1995), Eastman et al. (1997), Wang et al. (2005) and Ang et al. (2001) research in which English language is used. However, the questionnaire used in this study was translated into Indonesian language to ensure the understanding of the respondents towards the questions. There are four sections consisted of item scales and demographics information. The description of scale items and their validities and reliabilities are reflected in Table 2. Sections A and B measured social and personality factors. Section C evaluated attitudes and purchase intentions of counterfeits of luxury brands. Section D consisted of items about the demographic information of respondents. All items were measured on a seven-point Likert scale with 1 representing "strongly disagree" and 7 representing "strongly agree" (Phau and Teah, 2009).

\subsection{Variable Operational Definition}

The information susceptibility plays an important role for consumer before purchasing counterfeit products especially those who has little knowledge of the product category or product brand. The indicators used for the information susceptibility in this research are (Phau and Teah, 2009; Bearden et al., 1989): 1) Consumer observation before purchasing product, 2) Consumers' experiences of using product, 3) Consumers' possibility to consult others before purchasing product, 4) Consumer seeking information before purchasing product.

The consumers who have normative susceptibility would purchase a product based on what they assume the others would expect or want them to buy. The indicators used for the normative susceptibility in this research are (Phau and Teah, 2009; Bearden et al., 1989): 1) The influence of other's assumption to the consumer's buying decision, 2) The influence of other's expectation to the consumer's buying decision, 3) The influence of others impression to the consumer's buying decision, 4) The interest of consumer to imitate others.

Consumers that are value conscious will consider the quality of the product and the money they spend to buy the product. Therefore, consumers of counterfeit product will find that the counterfeit products are value for money. The indicators used for the value consciousness in this research are (Phau and Teah, 2009; Lichtenstein et al., 1990): 1) Concern to product quality and price, 2) Concern to product price and value, 3) Concern not to waste money for less quality product, 4) Concern to get high quality product at low price

Integrity is determined by personal ethical standards and obedience to the law, if it is critical, the chances of consumer viewing counterfeit products as favorable would be less, but if it is not important then they would be in favor of counterfeits (Ang et al., 2001; Wang et al., 2005). The indicators used for integrity in this research are (Phau and Teah, 2009; de Matos et al., 2007): 1) The value of honesty, 2) The value of politeness, 3) The value of responsibility, 4) The value of self-control

Personal gratification might influence the purchase decision of consumers to buy counterfeit product since buying a counterfeit product does not portray the consumer's accomplishment. The indicators used for personal gratification in this research are (Phau and Teah, 2009): 1) The importance of getting comfortable life, 2) The importance of getting an exciting life, 3) The importance of getting a sense of accomplishment, 4) The value of pleasure, 5) The value of social recognition.

Novelty seeking is the curiosity of individuals to seek variety and difference (Wang et al., 2005). The indicators used for novelty seeking in this research are explained by the following statements (Phau and Teah, 2009; Wee et al., 1995): 1) Be the firsts to try new products, 2) Excitement to purchase some interesting products, 3) Owning a lot of popular products, 4) Desire to keep up with fashion.

Status consumption is an obvious consumption of consumer products that symbolize status both for the individual and surrounding significant others (Heaney, 2005; Eastman et al., 1999). The indicators used for status consumption in this research are explained by the following statements (Phau and Teah, 2009; Eastman et al., 1997): 1) Interested in products with status, 2) Probability to buy product with status, 3) Probability to pay more for a product with status, 4) The irrelevance of a product status, 5) The value of a 'high status' appeal.

Attitude is a learned predisposition to respond to a situation in a favorable or unfavorable way (Huang et al., 2004). The indicators used for attitudes towards counterfeiting of luxury brands in this research are (Phau and Teah, 2009; de Matos et al., 2007; Wang et al., 2005): 1) Perception of reliability of counterfeit product, 2) Perception of similarity of counterfeit product, 3) Perception of function of counterfeit product, 4) The consequences of infringes intellectual property, 5) Disturbing the balance of the original product industry, 6) Consequences of damaging interests and rights of legitimate/original manufacturer.

The dependent variable analyzed in this study is purchase intention derived from the previous study conducted by Phau and Teah (2009), de Matos et al. (2007), and Ang et al. (2001). The indicators for purchase intention are: 
1) Alternative choices of buying counterfeit product, 2) Statement to buy counterfeit product, 3) Buying counterfeit product from peddlers.

Table 1. Items and $\alpha$ coefficient of the constructs

\begin{tabular}{|c|c|c|c|}
\hline Variables Measurement & Source & $\begin{array}{l}\text { Number } \\
\text { of Items }\end{array}$ & $\alpha$ \\
\hline $\begin{array}{l}\text { Information susceptibility } \\
\text { (IS) }\end{array}$ & $\begin{array}{l}\text { Phau and Teah (2009); } \\
\text { Bearden et al. (1989) }\end{array}$ & 4 & 0,890 \\
\hline $\begin{array}{l}\text { Normative } \quad \text { susceptibility } \\
\text { (NS) }\end{array}$ & $\begin{array}{l}\text { Phau and Teah (2009); } \\
\text { Bearden et al. (1989) }\end{array}$ & 4 & 0,810 \\
\hline Value consciousness (VC) & $\begin{array}{l}\text { Phau and Teah (2009); } \\
\text { Lichtenstein et al. (1990) }\end{array}$ & 4 & 0,900 \\
\hline Integrity (I) & $\begin{array}{l}\text { Phau and Teah (2009); de } \\
\text { Matos et al. (2007) }\end{array}$ & 4 & 0,796 \\
\hline Personal gratification (PG) & Phau and Teah (2009); & 5 & 0,826 \\
\hline Novelty seeking (NvS) & $\begin{array}{l}\text { Phau and Teah (2009); Wee et } \\
\text { al. (1995) }\end{array}$ & 4 & 0,854 \\
\hline Status consumption (SC) & $\begin{array}{l}\text { Phau and Teah (2009); } \\
\text { Eastman et al. (1997) }\end{array}$ & 5 & 0,791 \\
\hline $\begin{array}{lll}\text { Attitudes } & \text { towards } \\
\text { counterfeiting } & \text { bag } & \text { product } \\
\text { (Att) } & & \end{array}$ & $\begin{array}{l}\text { Phau and Teah (2009); de } \\
\text { Matos et al. (2007); Wang et } \\
\text { al. (2005) } \\
\text { Phau and Teah (2009); de }\end{array}$ & 7 & 0,838 \\
\hline Purchase intention (PI) & $\begin{array}{l}\text { Matos et al. (2007); Ang et al. } \\
\text { (2001) }\end{array}$ & 4 & 0,771 \\
\hline
\end{tabular}

\section{Research Findings}

\subsection{Descriptive Result}

The total usable sample was 250. The respondents in this research were the woman in the northern area of Yogyakarta, most of them were female (64\%) while only less of them were male $(36 \%)$. A total of $82 \%$ respondents were university students, the rest were private employee $(10 \%)$, civil servant $(3 \%)$, and housewife mother (5\%). Most respondents were $16-25$ years old (66\%), $24 \%$ of the respondents were $26-30$ years old, $10 \%$ of the respondents were 31-40 years old. Almost all of the respondents reported monthly income under Rp 1 million (85\%) and since the most respondents were university students, the marital status of the respondents were mostly single (84\%).

\subsection{Reliability Analysis}

The calculation of the coefficient correlation is conducted by using software SPPS 16.0, using Cronbach's alpha technique. The reliability is showed by the value of alpha, in which the value of 0.600 above is considered reliable. The result of the reliability analysis is presented in Table 2.

\subsection{Result of Hypothesis Testing}

The results of the path analysis by using SPSS software particularly on the path coefficient in Table 2 show that social factor have negative effect on attitudes towards counterfeit products, in this study the counterfeit product is women bags. This can be seen from the result of path coefficient (standardized regression weights estimate) between social factors and attitudes towards counterfeit bags is negative $(-0.183)$ and significant $(<0.05)$. Therefore, it can be said that the hypothesis $1 \mathrm{a}$ is accepted, followed by hypothesis $1 \mathrm{~b}$ which also supported by the result of path coefficient between value consciousness and attitudes of consumers towards counterfeit bags is positive $(0.163)$ and significant $(<0.05)$. Also, path coefficient between novelty seeking and attitudes towards counterfeit products are positive $(0.322)$ and significant $(<0.05)$ thus hypothesis $1 \mathrm{c}$ is accepted.

As other researches may show the significant result of integrity to influence the attitudes towards counterfeit products, the dimension of integrity in this study is proven to have significant negative effect on the attitudes towards counterfeit products. The path coefficient between integrity and attitudes towards counterfeit products is negative $(-0.278)$ and significant $(<0.05)$. Thus hypothesis $1 \mathrm{~d}$ is supported. As such, hypothesis $1 \mathrm{e}$ was also 
supported, proven from the path coefficient between personal gratification and attitudes towards counterfeit products is negative $(-0.235)$ and significant $(<0.05)$. In the other hand, while the hypothesis $1 \mathrm{a}-1 \mathrm{e}$ are supported, the path coefficient between status consumption and attitudes towards counterfeit products is not negative $(0.030)$ and insignificant $(>0.05)$ thus hypothesis $1 \mathrm{f}$ is not accepted.

Table 2. Regression to determinants of attitudes towards counterfeit products

\begin{tabular}{lllll}
\hline Variable & Path Coefficient & t-value & Sig. & Result \\
\hline SF & -0.183 & -4.719 & $0.000^{* *}$ & Significant \\
VC & 0.163 & 4.680 & $0.000^{* *}$ & Significant \\
NvS & 0.322 & 10.228 & $0.000^{* *}$ & Significant \\
I & -0.278 & -7.730 & $0.000^{* *}$ & Significant \\
PG & -0.235 & -7.388 & $0.000^{* *}$ & Significant \\
SC & 0.030 & 0.659 & 0.511 & Not Significant \\
& adjusted $\mathbf{R}^{2}$ & $=0.871$ & $\mathbf{F}$ & $=280.795$ \\
& $\mathbf{R}$ & $=0.935$ & Sig. & $=0.000$ \\
\hline
\end{tabular}

Notes: Dependent Variable: Attitudes towards counterfeit product; ${ }^{* *}$ significant at $\alpha=5 \%$

Source: Primary data (processed)

Moreover, as displayed in Table 3, the path coefficient between attitudes towards counterfeit products and purchase intention is positive $(0.762)$ and significant $(<0.05)$. It means that the attitudes towards counterfeit products will positively affect the consumers' purchase intention. Therefore, it can be said that the hypothesis 2 is accepted. Furthermore, the results of the path analysis show that social factors and attitudes towards counterfeit bags are positive $(0.251)$ and significant $(<0.05)$. Also, it is confirmed by the result of the path coefficient that value consciousness and purchase intention is positive $(0.218)$ and significant $(<0.05)$. Thus it can be inferred that hypothesis $3 a-3 b$ is supported. while novelty seeking, integrity, personal gratification and status consumption emerged not to have any significant relationship to purchase intention (sig. $>0.05$ ), thus hypothesis $3 \mathrm{c}-3 \mathrm{f}$ is rejected.

Table 3. Regression to determinants of purchase intention

\begin{tabular}{lllll}
\hline Variable & Path Coefficient & $\boldsymbol{t}$-value & Sig. & Result \\
\hline SF & 0.251 & 3.632 & 0.000 & Significant \\
VC & 0.218 & 3.513 & 0.001 & Significant \\
NvS & 0.030 & 0.470 & 0.639 & Not Significant \\
I & 0.119 & 1.728 & 0.085 & Not Significant \\
PG & -0.056 & -0.928 & 0.355 & Not Significant \\
SC & -0.064 & -0.807 & 0.420 & Not Significant \\
ATT & 0.762 & 6.944 & 0.000 & Significant \\
& adjusted $\mathbf{R}^{2}$ & $=0.622$ & $\mathbf{F}$ & $=59.556$ \\
& R & $=0.795$ & Sig. & $=0.000$ \\
\hline
\end{tabular}

Notes: Dependent Variable: Attitudes towards counterfeit product; ${ }^{* *}$ significant at $\alpha=5 \%$

Source: Primary data (processed)

\section{Discussion}

The social factors have negative effect on attitudes towards counterfeit products. As a woman who is influenced by social factors, both informative and normative, will not seek for counterfeits products, especially handbags, because normative people will care about other impression of what they wear. It means that people who rely on the expert opinion of others would be less favorable to wear counterfeit products. Meanwhile, the study also find that the social factors have a positive effect to the purchase intention, it might be because for certain extent, the normative people in Indonesia, in their effort to impress others, will probably purchase counterfeit handbags because they may not able to buy the original ones. 
The finding shows that value conscious consumers have positive effect on attitudes towards counterfeit products, and is also proven to have significant positive relationship to purchase intention of counterfeit products. The consumer often gives a judgment of value based on the brand rather than to the products itself. Therefore, it does not matter if their handbags are counterfeit ones as since they will still be able to wear Prada. The novelty seeking has positive effect on attitudes towards counterfeit products. People who seek for novelty will find something new to try and thus may influence them to try using counterfeit products. However, the path coefficient shows that there is no significant relationship between novelty seeking and purchase intention of counterfeit products. The result also shows that integrity has significant negative effect on attitudes towards counterfeit products, because people who have integrity will not be interested in using counterfeit product since they appreciate to the originality of a product and they are also aware of the social consequences if using counterfeit products. Furthermore, integrity has no significant relationship to purchase intention of counterfeit products and this finding strengthens the statement that people with integrity will not be likely to purchase counterfeit products.

People who tend to have personal gratification will not buy something non-original because a clone will not satisfy their desire. It is proven by the result of the study that the personal gratification has negative effect on attitudes towards counterfeit products, even has no significant relationship to the purchase intention of counterfeit products. Moreover, the result of this study finds that status consumption has no significant relationship to both of the attitudes towards counterfeit products and purchase intention of counterfeit products. The logic is that people who concern with their status will not prefer to purchase counterfeit handbags. Apparels can be used to define someone's status and passively determine their level, in the social lifewearing an imitation will decrease their pride. This finding supports the previous study by Nordin, N (2009).

Apparently, the attitudes towards counterfeit products have positive effect on purchase intention of counterfeit products. As such, Hidayat and Phau (2003a; 2003b) previously found that people who have more interest to counterfeit products will also tend to have more encouragement to buy counterfeit products. This result corresponds to the findings of past research (Phau and Teah, 2009; De Matos et al., 2007; Huang et al., 2004). As addition, Hidayat and Ekasasi (2012) shown that no matter high or low product involvement, willingness to buy counterfeit branded product was positively related to attitudes towards counterfeit. It is evident that consumers' attitude towards counterfeit products plays an important role in leading or driving the consumer purchase intention.

\section{Conclusion}

The antecedents of social and personality factors mostly have significant effect on attitudes towards counterfeit products of Indonesian consumers. This indicates that the social factors have significant negative effects on attitudes towards counterfeit products. Meanwhile, the factors derived from personality factors are all having significant effecnt on attitudes towards counterfeit products and only status consumption show the insignificant result. Therefore, it can be concluded that social and personality factors affect the attitudes of consumer towards counterfeit products.

Similarly, result of the hypothesis confirms that there is significant effect between the attitudes and purchase intention towards counterfeit products. The finding of this research are similar to the previous research conducted in China and Malaysia (Phau\&Teah, 2009; Nordin, 2009), thus it can be used to enrich the study about the attitudes and purchase intention towards counterfeit products. This can be inferred that consumer attitudes towards counterfeit handbags product will positively influence the consumer to purchase counterfeit products.

In the contrary, the path coefficient shows that there is only a little significant relationship between social and personality factors and purchase intention towards counterfeit products. Out of six variables only two variables are proven to have significant effect on purchase intention towards counterfeit products, which are social factors and value consciousness. Thus can be stated that social and personality factors have no or less considerable effect towards purchase intention.

As the study is a snapshot of the Indonesian consumers in the urban areas of the newly rich, extensions to populations of other areas in Indonesia of different socio economic groups and to other countries may produce different results. Also, factors such as perceived benefit, intrinsic and extrinsic cues, lawfulness, and more are not included in this study, thus their influence to the attitudes towards counterfeit products are unknown. Nevertheless, counterfeit product are a sensitive object, to ask the respondents provide their experiences buying or consuming counterfeit product was challenging since it may affects their status or image. Besides, it is suggested to the marketer of the original product have to be more courage to directly campaign against 
counterfeit products, also they have to differentiate their product and giving more product variety. The role of the Indonesian government also important as to concern seriously to give punishment to the producer of counterfeit products, not only handbags but also for any other products therefore the original product will keep their existence.

\section{References}

Ajzen. (1991). The Theory of Planned Behavior. Organizational Behavior and Human Decision Processes, 50(2), 179-211. http://dx.doi.org/10.1016/0749-5978(91)90020-T

Ang, S. H., Cheng, P. S., Lim, E. A. C., \& Tambyah, S. K. (2001). Spot the difference: Consumer response towards counterfeits. Journal of Consumer Marketing, 18(3), 219-235. http://dx.doi.org/10.1108/07363760110392967

Bearden, W. O., Netemeyer, R. G., \& Teel, J. E. (1989). Measurement of consumer susceptibility to interpersonal influence. Journal of Consumer Research, 15, 473-481. http://dx.doi.org/10.1086/209186

Budiman, S. (2012). Analysis of Consumer Attitudes to Purchase Intentions of Counterfeiting Bag Product in Indonesia. International Journal of Management, Economics and Social Sciences, 1(1), 1-12.

Chakraborty, G., Allred, A., Sukhdial, A. S., \& Bristol, T. (1997). Use of negative cues to reduce demand for counterfeit products. Advances in Consumer Research, 24, 345-349.

Cheung, W. L., \& Prendergast, G. (2006). Buyers' perceptions of pirated products in China. Marketing Intelligence \& Planning, 24(5), 446-62. http://dx.doi.org/10.1108/02634500610682854

Cordell, V., Wongtada, N., \& Kieschnick, R. L. Jr. (1996). Counterfeit purchase intentions: role of lawfulness attitudes and product traits as determinants. Journal of Business Research, 35(1), 41-53. http://dx.doi.org/10.1016/0148-2963(95)00009-7

De Matos, C. A., Ituassu, C. T., \& Rossi, C. A. V. (2007). Consumer attitudes toward counterfeits: a review and extension. Journal of Consumer Marketing, 24(1), 36-47. http://dx.doi.org/10.1108/07363760710720975

Eastman, J. K., Fredenberger, B., Campbell, D., \& Calvert, S. (1997). The relationship between status consumption and materialism: a cross-cultural comparison of Chinese, Mexican, and American students. Journal of Marketing Theory and Practice. Winter.

Eisend, M., \& Pakize, S-G. (2006). Explaining Counterfeit Purchases: A Review and Preview. Academy of Marketing Science Review, 10(2), 1-25.

Hidayat \& Ekasasi. (2012). Lawfulness attitudes of Indonesian consumers toward purchasing of counterfeit branded product. The 19th International Conference on Recent Advances in Retailing and Services Science.

Hidayat \& Phau. (2003a). Product Counterfeiting: The "New Worldwide Real Product" Without Business Risks. A Proposed Study of the Demand and Supply sides Investigations. World Marketing Congress Proceeding, June 11th-14th, Perth.

Hidayat \& Phau. (2003b). A Review of Product Piracy: The Emergence of "New Real" Business without Boundaries and Risks. Working Paper Series, CBS Curtin Technology of University, pp. 31-37.

Huang, J. H., Lee, B. C. Y., \& Ho, S. H. (2004). Consumer attitude toward gray market goods. International Marketing Review, 21(6). 598-614. http://dx.doi.org/10.1108/02651330410568033

Husic, M., \& Cicic, M. (2009). Luxury Consumption Factors. Journal of Fashion Marketing and Management, 13(2), 231-245. http://dx.doi.org/10.1108/13612020910957734

Jakarta, G. (2012). $\quad$ Retrieved from www.thejakartaglobe.com/home/indonesia-among-worlds-worstcounterfeit-goods-offenders-us-report/5152 93

Kay, H. (1990). Counterfeiting: Fake's progress. Management Today, 54-58.

Lichtenstein, D. R., Netemeyer, R. G., \& Burton, S. (1990). Distinguishing Coupon Proneness From Value Consciousness: An Acquisition-Transaction Utility Theory Perspective. Journal of Marketing, 54, 54-67. http://dx.doi.org/10.2307/1251816

Nordin, N. (2009). A Study on Consumers' Attitude towards Counterfeit Products in Malaysia. A Ph.D. Dissertation, University of Malaya, Malaysia.

Penz, E., \& Stöttinger, B. (2005). Forget the "real" thing-take the copy! An explanatory model for the volitional 
purchase of counterfeit products. Advances in Consumer Research, 32(1), 568-575.

Phau, I., \& Teah, M. (2009). Devil wears (counterfeit) Prada: a study of antecedents and outcomes of attitudes towards counterfeits of luxury brands. Journal of Consumer Marketing, 26(1), 15-27. http://dx.doi.org/10.1108/07363760910927019

U.S. Customs and Border Protection Office of International Trade. (2007). Department of Homeland Security U.S. Customs and Border Protection and U.S. Immigration and Customs Enforcement FY 2007 Top IPR Commodities Seized. $\quad$ Retrieved September 1, 2012, from http://www.cbp.gov/linkhandler/cgov/trade/priority_trade/ipr/seizure/trading/07_topirp_seizures.ctt/07_topi rp_seizures.pdf

Wang, F., Zhang, H., Zang, H., \& Ouyang, M. (2005). Purchasing pirated software: an initial examination of Chinese consumers. Journal of Consumer Marketing, 22(6), 340-51. http://dx.doi.org/10.1108/07363760510623939

Wee, C.-H., Tan, S.-J., \& Cheok, K.-H. (1995). Non-price determinants of intention to purchase counterfeit goods. International Marketing Review, 12(6), 19. http://dx.doi.org/10.1108/02651339510102949

\section{Copyrights}

Copyright for this article is retained by the author(s), with first publication rights granted to the journal.

This is an open-access article distributed under the terms and conditions of the Creative Commons Attribution license (http://creativecommons.org/licenses/by/3.0/). 